\title{
Introduction: The Future of Chinese Law*
}

\author{
Stanley Lubman
}

The interaction between the millennial dominant orientations of Chinese culture and the entire impact of modernization and of Marxism-Leninism is a story that is unfolding before our eyes, and we have no neat formula for predicting its outcome. ${ }^{1}$

By focusing on legal reforms this Special Issue of The China Quarterly draws attention to a group of institutions whose fate is crucial for China's future. The economic reforms that have transformed China since the late 1970s are generating new institutions and transactions that demand legal definition. The surge of foreign direct investment that has made China the world's largest capital-importing country makes necessary further development of the legal framework for foreign trade and investment. Moreover, forces broader and needs deeper than those produced by economic development will also help to impel Chinese law reforms.

When the Chinese leadership turned its attention to creating a legal order after the end of the Cultural Revolution, one of its expressed concerns was to reduce official arbitrariness. Even though the totalitarian grip of the Chinese Communist Party has weakened since then, concerns about arbitrariness are no less and can only increase. Furthermore, if China is to cope with the many problems that are by-products of economic reform, including a decline in social order, spreading corruption and a general crisis of values, it will need strong legal institutions and a legal culture that promotes the rule of law. The rule of law has become an issue for many more Chinese than just their leaders or intellectuals.

This introduction attempts to weave together some of the salient insights of the other articles in this issue, emphasizing possible trends in future developments. All the articles reflect marked progress in a realm that for decades was neglected by China's rulers. Law was inextricably entwined with politics from the birth of Maoist China and politicized into irrelevance during the Cultural Revolution; only in recent years has it begun to evolve, unevenly and slowly, into a distinct body of rules and institutions. The articles signal this slow evolution, touching on the growing complexity and professionalism of the legislative process; the struggle of the courts to enforce their judgments in civil cases and thereby to buttress the general application of the laws; the attempts of the courts to deal with the challenge of interpreting the rapidly growing body of legislation; the ambiguous role of law in balancing control of foreign investment against facilitating the activities of foreign-invested enterprises; the issues posed by the rapid growth of the Chinese bar; and

*This Special Issue was made possible by the generous support of a grant from the Henry Luce Foundation.

1. Benjamin Schwartz, China's Cultural Values (Tempe, AZ: Center for Asian Studies, Arizona State University, 1993), p. 19.

(C) The China Quarterly, 1995 
the tensions between broad legislative attempts to shape family life and resistance to legislation from various sectors of Chinese society.

To some foreign eyes, the glass into which they peer may seem to be filling, especially when they count up laws and regulations. There is, however, much evidence to suggest how empty the glass remains. A number of themes can be discerned that all or most of these articles touch on in some way. An unhappily familiar one is that the Chinese criminal process continues to reflect overt links between law and policy. A second theme is that in all matters, the judicial system is in practice only one of a number of the bureaucratic hierarchies that make up the apparatus of the Chinese state. To say that the courts are at best only co-ordinate with those other bureaucracies is only another way of expressing how far away China is from establishing a notion of the supremacy of law, at least as that concept is conceived in the West. In various ways, then, the articles echo the familiar idea that law is still frequently conceived, as William Alford has observed elsewhere, as "a tool of state administration,"2 and always within close reach of the Chinese Communist Party (CCP).

Another theme of fundamental importance that emerges from these articles is the pervasive influence of a number of strands in Chinese legal culture. Persistent traditional attitudes do not encourage a high degree of rights-consciousness while ideology and the views of the leadership restrain the role of law, and Western and Overseas Chinese influences seem to thrust in different directions. The contention among these various elements of legal culture demonstrates the interplay of the larger forces encompassed by Benjamin Schwartz's observation that is quoted at the beginning of this article.

This article first draws together the views of the authors in the pieces that follow on the building of new institutions, the effort which has been at the centre of reform efforts. Against that background it attempts to identify the principal functions that the new legal institutions seem to serve. It then speculates on possible tendencies in the future of likely major determinants of the course of Chinese legal reforms: the strength of the Chinese state itself, the relations between state and society, and the impact of some of the various major components of Chinese legal culture. The conclusion attempts to place all these elements in a final speculation.

\section{Institution Building}

Out of necessity, most of the efforts of the first decade and a half of legal reform had to be focused on building new institutions. The recent accomplishments of law reform are considerable when measured against the state of Chinese law when the reform began in 1979. The tragedy of the Cultural Revolution was so intense and long-lasting that it obscured the extensive politicization of law that had occurred long before the onset of that cataclysm. Years before the Red Guards made their spectacular

2. William P. Alford, "Seek truth from facts-especially when they are unpleasant: America's understanding of China's efforts at law reform," Pacific Basin Law Journal, Vol. 8 (1990), pp. $177-196$ at p. 182. 
and ill-fated appearance, China under Mao had already discarded the Stalinist models that had been adopted and only intermittently and inconsistently implemented during the mid-1950s, in favour of even more politicized institutions. The Anti-Rightist campaign of 1957-58 had branded as rightists and purged legal scholars and officials who had dared to suggest, while a "Hundred Flowers" had briefly bloomed, the desirability of a legal system less slavishly tied to the CCP. By the beginning of the 1960s, well before Mao launched the Cultural Revolution, the number of law schools had been reduced, the experimental bar abolished and the law school curriculum increasingly politicized.

Legal reform did not begin until almost twenty years later. Because of the lack of substance of Chinese legal institutions before the Cultural Revolution and their subsequent disappearance, legal reform has included the revival of some institutions, such as the judicial system - with the attendant consequence of restoring its role as an instrument of CCP rule - and the creation of entirely new legal institutions.

The legislative explosion. Since 1979 whole areas of law have been embraced by new codes and statutes. Examples include the General Principles of Civil Law which, although truncated by comparison to the European and Taiwan legislation that inspired it, is the current version of a civil code. ${ }^{3}$ It is supplemented by the Economic Contract Law as well as laws on particular kinds of contracts and other economic transactions. A Civil Procedure Code was adopted and then amended; after a long gestation period a new Company Law was promulgated in 1993. Reflecting the move away from a planned economy, new transactions have appeared, necessitating the drafting of laws for entire new substantive areas such as securities and the use of mortgages to secure obligations. At the same time, impressionistic evidence suggests that there seems to be less frequent use of "internal" (neibu) laws and regulations.

Emerging functional specialization in drafting laws. The economic reforms add complexity to Chinese society that must be addressed by new legislation, and Murray Scot Tanner explores the development and articulation of the legislative process. Tanner has already shown elsewhere that specialists in legislation have begun to participate in lawmaking. ${ }^{4}$ In this issue he examines the principal arenas of legislative policy-making, the National People's Congress (NPC) and the State Council, and identifies the stages of the legislative process and some of the dynamics of the interactions among various participants. He notes that legislative proposals may be initiated from among an increasing variety of political actors, with the result that the process is "more hospitable to relatively

3. William C. Jones, "Some questions regarding the significance of the General Provisions of Civil Law of the People's Republic of China," Harvard Journal of International Law, Vol. 28 (1987), p. 309.

4. Murray Scot Tanner, "Organizations and politics in China's post-Mao law-making system" in Pitman B. Potter (ed.), Domestic Law Reforms in Post-Mao China (Armonk, NY: M.E. Sharpe, 1994) pp. 56-96. 
innovative policy ideas, and more accessible to a wide variety of nonbureaucratic groups and interests" models might suggest. He analyses the process and politics of consensusbuilding, the functions of debate in the NPC and some of the various uses of implementing legislation.

Tanner concludes that although the NPC is a weak legislature, its reviews of proposed legislation are no longer perfunctory or a "simple public show of 'socialist democracy'," and that the NPC has begun to exercise something more than a "rubber-stamp" function. ${ }^{6} \mathrm{He}$ suggests, at the same time, the possible mixed consequences of more openness in the Chinese legislative process: although it may be better suited to produce laws needed to support market-oriented economic reforms it may also afford more access to groups in society that fear the risks of such reforms.

Development of processes of interpretation. The experience of Western nations suggests that as legislative activity increases courts are impelled to exercise an interpretative function because of the needs for coherence, internal consistency and rationality in applying legislation and, not incidentally, because the discretion of officials who must apply the laws in practice must be controlled. If specialization and the evolution of a legislative process are beginning to alter the legislature in such a way as to increase the number of voices that make themselves heard in shaping new laws, what traces of institutional evolution are there in the courts? To Westerners, especially in common-law countries, it seems proper to endow the courts with interpretative functions, whereas in China ideology, constitutional theory and administrative practice have all denied the courts authority to interpret legislation, which is usually characterized as a legislative rather than a judicial function. ${ }^{7}$ Tanner ends his article with a brief note on the emergence of an aggressive and creative role for the Supreme People's Court, which issued implementing regulations for the General Principles of Civil Law that he finds much like the regulation that is usually drafted by the Legislation Bureau of the State Council to explicate general legislation. ${ }^{8}$ Recent scholarship has called attention to the growth of the Court's interpretative, lawmaking activities. ${ }^{9}$

5. Tanner, p. 64 .

6. His conclusions add interest to NPC Vice-Chairman Tian Jiyun's suggestion that rather than let legislation be allowed to come forward from "departments concerned," it was desirable for the NPC Standing Committee and its Special Committees to "organize and take the lead in drafting some laws," "Tian Jiyun on laws for market economy," Foreign Broadcast Information Service, Daily Report, China (hereafter FBIS-CHI), 23 July 1993, p. 36 at p. 37.

7. See e.g. Guiguo Wang, Business Law of China: Cases, Text and Commentary (Hong Kong: Butterworths Asia, 1993) p. 36 and authorities there cited.

8. See William C. Jones, "The significance of the Opinion of the Supreme People's Court for civil law in China" in Potter, Domestic Law Reform in Post-Mao China, pp. 97-108. Jones views the Opinion differently, concluding that it "provides rules for deciding minor problems but makes no effort to be complete nor to deal with serious interpretive issues" (p. 103).

9. Nanping Liu, “' 'Legal precedents' with Chinese characterstics; published cases in the Gazette of the Supreme People's Court," Joumal of Chinese Law, Vol. 5 (1991), pp. 107-141; Susan Finder, "The Supreme Cour of the People's Republic of China," Journal of Chinese 
Anthony Dicks closely examines some examples of interpretation by courts and administrative agencies. He emphasizes the significance and strength of what he characterizes as "legal fragmentation," which permits different parts of the bureaucracy to interpret the same rules, causing the multiplication of "logically inconsistent rules of substantive law." 10 This modern practice is consistent both with traditional Chinese legal culture, which did not recognize the separation of powers, and with MarxismLeninism, which insists that only legislatures may interpret legislation. He concludes that in practice China has "some of the worst disadvantages of federal legal systems without the appropriate legal and political machinery even to resolve the resulting conflicts and tensions, far less to unify the law." In addition to illustrating the deference of the courts to the CCP, Dicks gives examples from practice to show that when the courts are presented with issues that involve the jurisdiction of other agencies as well as their own, they may negotiate joint interpretations, follow administrative interpretations or refuse jurisdiction altogether and defer to an administrative agency to decide questions involving the interpretation of a law or regulation. Dicks suggests that this degree of deference by the courts calls into question whether, "despite their superficial resemblance [to Western courts] they can be regarded as functionally comparable institutions," 12 and concludes that his analysis "throws doubt on the authority of the courts as exponents of a generalized and universally applicable view of the law."13 Dicks' article suggests that economic and legal reform are likely to continue to create both the need and pressure to expand the interpretative power of the courts, but their current ability to respond to the challenge appears to be highly restrained.

Dispute settlement. It has been easier to produce law codes than a competent judiciary to apply them. Litigation over economic matters is considerable. Although the nearly 600,000 economic cases handled by the people's courts at all levels in 1990 was almost 15 per cent less than in the previous year, ${ }^{14}$ the number rose again to 650,000 in 1992. ${ }^{15}$ Despite the increase in litigation, however, enforcement of the judgments of the courts is weak, with "regional protectionism" a prominent cause. The Chief Justice of the Supreme People's Court has stated that 'in recent years, 'local protectionism' has seriously affected the judicial work of the courts." 16 One foreign scholar has commented that

\footnotetext{
footnote continued

Law, Vol. 7 (1993), pp. 225-275, concluding that "the Court is involved in interpreting law, legislating, adjudicating, as well as administering the judicial system." p. 223.

10. Dicks, p. 93.

11. Ibid. p. 84 .

12. lbid. pp. 94-95.

13. Ibid. p. 109.

14. "Ren Jianxin delivers Supreme People's Court work report," BBC Summary of World Broadcasts, 25 April 1991, Part 3, Special Supplement FE/1055/C1/1 at p. 6.

15. "Supreme People's Court Work Report," FBIS-CHI, 7 April 1993, p. 17 at p. 19.

16. Quoted in Matthew D. Bersani, "The enforcement of arbitration awards in China," Journal of International Arbitration, Vol. 10 (1993), pp. 47-53 at p. 49.
} 
"The most controversial question in Chinese civil process today is enforcement. It may seem extraordinary that in an authoritarian state like China the courts simply cannot enforce their decisions in civil cases."17

Donald Clarke's study of the enforcement of civil judgments goes beyond "local protectionism" to raise what may be the most significant implications of all the articles for the meaningfulness of Chinese legal institutions in practice. He argues that the ineffectiveness of Chinese courts in enforcing civil judgments arises in part from the fact that they are considered by nonjudicial officials to be coequals in the bureaucratic apparatus of the Chinese state. ${ }^{18}$ Among the consequences of this perception is low status, as a recent Chinese comment indicates:

The people's courts are a part of the state organ [sic] and judges are a part of the state's government functionaries; they are no different from other state cadres in identity and status. It requires no special process for someone to become a judge. The qualifications of judges are uneven.... In addition, their salary is low; they have little social status.... 19

A more decisive constraint on the capacity of the courts to develop either professionalism or autonomy is the continuing role of CCP officials, who can influence the outcome of individual cases at all levels. There seems little doubt that in criminal cases, and not just those with overtly political implications that involve allegedly counter-revolutionary activities, CCP officials at the courts can determine guilt and punishment. An attempt in 1979 to remove them from day-to-day court work failed, and there does not seem to have been any change since then. ${ }^{20}$ Feinerman and Clarke, in their article on criminal law, cite vivid assertion of CCP power over what is still known to the Party as "political-legal" work. ${ }^{21}$

The bar. If the courts are undeveloped, the bar seems even more so. William Alford notes the new challenges facing the new lawyers, for which neither Chinese tradition nor China's recent history have prepared them. As Alford comments, "barely one-fifth of Chinese lawyers have earned law degrees and many of those studied law for a centrally planned economy, much of which has been superseded, and in a manner hardly conducive to the cultivation of analytical skills." 22 They are ill-prepared to work as autonomous lawyers rather than as "state legal workers."23

17. Edward J. Epstein, "Editor's notes," China Law \& Practice, Vol. 5 (17 June 1991), p. 61 at p. 65 .

18. See also Lucie Cheng and Arthur Rosett, "Contract with a Chinese face: socially embedded factors in the transformation from hierarchy to market, 1978-1989," Journal of Chinese Law, Vol. 5 (1991), pp. 143-244 at p. 242: "Courts are creatures of the level of government ... that creates them, appoints the judges, and which continues to supervise in detail their activities."

19. Yang Kaixiang, "A comparative study of judges' status," Shanghai faxue (Jurisprudence), No. 137 (10 April 1993), translated as "Judges' status in judicial system discussed," JPRS-CAR-93.041, 21 June 1993, p. 28.

20. Hikota Koguchi, "Some observations about 'judicial independence' in post-Mao China," Boston College Third World Law Journal, Vol. 5 (1987), pp. 195-213.

21. Clarke and Feinerman, pp. 152-53.

22. Alford, p. 31 .

23. Ibid. p. 32. 
Moreover, there is much to suggest that the leaders of the PRC and, specifically, of the Ministry of Justice, are accustomed to thinking of neither the bar nor the law itself as autonomous. The clearest example of continuing limits on the expansion of the role of the lawyer lies in the criminal process, where, as Clarke and Feinerman point out, the lawyer generally lacks a meaningful ability to assert his client's innocence. ${ }^{24}$

Alford is pessimistic about the prospects for rapid growth of the profession and the development of professional standards of ethics and responsibility, noting that even if the Ministry of Justice attains its goal of producing 100,000 new lawyers by the year 2000 , only half of them will have law degrees. Behind this depressing fact are other questions that are not discussed in this issue, of the nature and quality of Chinese legal education itself.

Alford summarizes the enormous problems facing the Chinese legal profession, which include the difficulty of transforming the mentality of "state legal workers" into that of an independent profession and the temptation to lawyers, judges and officials who regulate the legal profession to engage in bribery and a variety of corrupt practices that currently pervade their professional activities. He highlights the tension between well-meaning steps to define standards and the failure to change habits of thought and outlook that were necessary in a totalitarian society. Underlying these difficulties is the contradiction between establishing a legal profession and CCP opposition to autonomous organizations and professions. Alford in particular notes that

If...the function of legal professionals is to reconcile public and private interests, the absence of clear, broadly shared understandings of what these interests are at a time when the contents of the Party's core ideology and of morality itself are increasingly open to contestation and manipulation leaves lawyers without more than a highly personalized basis for framing such reconciliations. ${ }^{25}$ (emphasis added)

The dilemmas of the Chinese legal profession thus reflect the profound philosophical, moral and ethical problems that trouble Chinese society. At the same time, Alford cautions against strict application of Western standards, with a reminder that many of the ethical problems that confront Chinese practitioners are difficult for Western lawyers to deal with and that the high ideals of the legal profession in the West have been impaired as that profession becomes "just another business." 26

The legal framework for foreign trade and investment. Of all the legal institutions that have appeared since the reforms began in the $1980 \mathrm{~s}$, those concerned with foreign investment have developed the fastest. Chinese legal reform is by no means intended to benefit foreigners only, or even principally, but the policy of "opening" and the consequent influx of foreign direct investment into China added urgency to the effort to create a foreign investment regime. Behind the edifice of laws and regulations that has been erected since the promulgation of the first law

24. Clarke and Feinerman, p. 140.

25. Alford, p. 36.

26. Ibid. p. 37. 
on joint ventures in 1979, however, lies the intention of the Chinese government "to supervise foreign business activity closely."27 Policy has not been clear, however (Potter rightly speaks of "policy indeterminacy") nor has it been consistent, as Potter and Feinerman each illustrate. ${ }^{28}$ Potter notes that investors' confidence is endangered because of their perception of a widespread lack of uniformity and consistency in interpreting and implementing laws and regulations, and Feinerman also gives specific examples of foreign investors' concerns in specific areas, emphasizing disparate tax treatment, changing government policy on convertibility of RMB earned by Sino-foreign joint ventures on the domestic market, flexible conceptions of contract and Chinese resistance to third-party resolution of commercial disputes.

Potter notes some factors that are likely to have negative effects on the future development of the regime governing foreign investment. He observes that although the success of the Asian "dragons" in promoting economic growth to some extent stems from their strong reliance on the state as the "critical catalyst for development,"29 Chinese policy towards foreign investment has been inconsistent, moving "between extremes of openness and restriction." 30 Among the many differences between the Asian NICs and China, of course, is that China has been travelling an uncertain path leading from totalitarianism to as yet undefined goals involving, inconsistently, both establishment of a market economy and maintenance of the continued rule of a Leninist party. As long as the ultimate goals of reform remain both vague and self-contradictory the legal rules applicable to foreign investment are likely to continue to reflect more basic Chinese dilemmas. Moreover, Potter argues, whatever the control over foreign investment desired by Chinese leaders in Beijing, the growth of local autonomy and the increase in corruption threaten to weaken the power of the state over foreign business in China.

China and the international legal order. James Feinerman's study illuminates Chinese ambivalence toward many of the norms of international law and suggests its relationship to Chinese legal culture. His conclusion is that China "more frequently scoffs at international law than its own recent rhetoric and the writings of some sympathetic foreign observers would have the rest of the world believe,"31 and indeed Chinese behaviour in a number of areas has caused other observers to express similar sentiments. ${ }^{32}$ At the same time, the development of domestic legal

27. Potter, p. 167.

28. See e.g. Potter, pp. 174-76, Feinerman, p. 193.

29. Potter, p. 156.

30. Ibid. p. 174.

31. Feinerman, pp. 186-87.

32. When it was reported that eight Chinese athletes had tested positive for drug usage at an international competition, one observer noted that when China lost face in sport circles "its credibility was harmed in a broader sense, at a moment when it is seeking closer integration with the international community." "Swimmer's reputation takes a dive: the embarrassment of China's drug-shamed sports leaders," Financial Times, 3 December 1994. Earlier in 1994, China became "the first country to flout the conventions of space by parking a satellite in a position that could interfere with other satellites and hinder the Asian ambitions of 
institutions has made the Chinese leadership more conscious of the need to observe international law, even on such issues as human rights, on which the Chinese leadership rejects Western values but has increasingly come to discuss the issues using Western concepts. Yet Feinerman also finds that the Chinese are undermining Western attempts to halt the proliferation of nuclear and non-nuclear weapons, and on Hong Kong he finds the "utter disregard of Beijing for its treaty obligations and responsibility to preserve Hong Kong's pre-1997 system after assuming control.,"33

\section{Some Emerging Functions of Chinese Legal Institutions}

By what standards should Chinese legal reforms be measured? The study of Chinese law, like that of any foreign law, necessarily requires the observer to grapple with the problem of articulating the categories and concepts to be applied to the object of study. Because law is the most overtly culture-bound of all the disciplines, legal studies of China raise with particular sharpness issues that bedevil all implicitly or explicitly comparative inquiries into Chinese society. ${ }^{34}$ Comparative legal study generally has been conspicuously unsuccessful in developing concepts that aim at cultural neutrality. ${ }^{35}$ Some observers generalize from Western law and are quite willing to assume the universality of Western legal forms and legal ideals regardless of the risks of cultural bias. At the other extreme, cultural relativism negates analysis altogether.

It seems useful to assess Chinese legal reform in terms of the functions of the particular legal institutions in question, and thereby express a methodological approach that is intended to rise above the exclusive use of Western categories of legal concepts. A handful of obvious and relatively noncontroversial functions of law have been used here to enable comparison of post-reform institutions with those of the first 30 years of the PRC, suggesting marked movement away from the most overtly politicized uses of the "political-legal apparatus," as legal institutions were previously known. ${ }^{36}$ Reform manifests an intention to endow law with functions that were never before in the history of the PRC considered appropriate. At the same time, some important functions of law in the West have not been promoted.

footnote continued

international broadcasting companies." "Beijing flouts convention on satellite parking," Financial Times, 2 August 1994.

33. Feinerman, p. 208.

34. See, discussing comparative study of Chinese culture generally, Andrew Nathan, "Is Chinese culture distinctive?" The Journal of Asian Studies, Vol. 52 (1993), pp. 923-936.

35. Gunter Frankenberg, "Critical comparisons: re-thinking comparative law," Harvard Journal of International Law, Vol. 26 (1985), p. 411 at pp. 434-40.

36. Limitations on space prevent further consideration of the thorny problem of defining the categories of analysis, including other functions that could be usefully employed in analysis. Tanner, in his paper, mentions "differing roles of legislation," and enumerates: cementing policy changes; hortatory calls for some desired behaviour; vehicles for policy debate; and declarations of policy intent for domestic and foreign purposes. 
Law and mobilization. The most obvious change is the rise of conceptions of law unrelated to supporting short-term political activity. During the 1950s and 1960s law was used as an overt instrument of policy, so that both dispute settlement and the criminal process were commonly used to support current policies, especially during political campaigns. The courts are now less overtly used to mobilize the populace, simply because the style of Chinese politics has changed and the effectiveness of mobilizational tactics has declined. ${ }^{37}$ This function has greatly shrunk, especially in its most violent and public manifestations, but the use of campaign-type emphases, especially to punish crime, indicates that it has not disappeared.

Law and social control. Law was almost totally identified as a instrument for social control throughout the history of the PRC until economic reform began to promote other functions that now jostle for attention. There has been frequent expression of the need for more laws and a strong legal system to maintain "political stability and good social order." ${ }^{38}$ The instrumental use of the courts as part of the state apparatus of control is demonstrated by their support of nation-wide campaigns to punish crime, ${ }^{39}$ repress dissidents and join in the general struggle to maintain social order. Thus, President of the Supreme People's Court Ren Jianxin could refer in his annual court report in 1993 to a three year "anti-theft campaign" that had been decided by the Central Committee of the CCP on "Comprehensively Dealing With Public Security."40

The extent to which the formal criminal process continues to serve totalitarian control is illustrated in Clarke and Feinerman's article in this issue. They note that pretrial detention, which is often imposed far longer than the statutory three months, blurs the line between investigation and punishment. The frequency of arbitrary arrest and detention and the use of torture are among the characteristics of Chinese criminal procedure that Clarke and Feinerman point to as violating Chinese norms as well as international standards of human rights.

The subordination of the courts to higher political concerns is also manifested by the limits on their jurisdiction. The courts do not hear many cases in which the accused is a CCP member. Continuing a practice that originated long before 1949, extra-judicial agencies may be employed to punish CCP members who have committed crimes. A Hong Kong newspaper reported in April $1994^{41}$ that the CCP will grant

37. They continue to appear from time to time. In the early 1980 s, even though the leadership had eschewed the use of campaigns, the creation of new legal institutions led to a propaganda offensive to educate the Chinese populace about the new institutions and promote their use. See e.g. Stanley Lubman, "Emerging functions of formal legal institutions in China's modernization," China Law Reporter, Vol. 2 (1983), pp. 195-266 at p. 238.

38. "Jiang links strong legal system, successful reform," FBIS-CHI, 16 December 1992, p. 19.

39. Note, "Concepts of law in the Chinese anti-crime campaigns," Harvard Law Review, Vol. 89 (1985), p. 1890.

40. "Supreme People's Court work report," p. 19.

41. "Anti-corruption drive starts," Eastern Express, 20 April 1994. 
"sweeping" enforcement powers to CCP officials investigating corruption, including the right to confiscate travel documents, videotape suspects without their knowledge and freeze bank accounts. The new measures were announced by the CCP Central Discipline Inspection Committee. The report further stated that these are powers that formerly were granted only to the Public Security Bureau, the procuracy and the Ministry of State Security and adds that "some jurists have questioned whether allowing Communist Party bodies to operate directly with law enforcement powers complies with China's state constitution." The continued separation of Party discipline from legality maintains the CCP beyond the reach of the law and expresses the related reluctance to elevate the courts above other elements of the Chinese party-state.

The courts have no jurisdiction over a wide number of crimes that are relegated to the PSB (police) to punish as administrative matters. Clarke and Feinerman observe that the formal process is less important than the administrative punishments imposed by the police, which they style as a "loose cannon." In addition to imposing low-level punishments for minor offences $^{42}$ the police may also sentence offenders to "labour re-education" for as long as three years for offences that are defined in "loose rules" and "simple and moralistic language." 43

The uses of law to attempt to buttress social control may also be considered from a substantive angle, as Michael Palmer does in his article on family law. He notes continuing strong concern, stemming from the early history of the PRC, to shape the family according to the dictates of Marxist-Leninist doctrine so that it will support the socialist state. He focuses on the rules on marriage registration, divorce and attempts to control reproduction, finding that each area reflects strong intentions to influence the family in ways that would contribute to social stability and order. But he also suggests that in various quarters of Chinese society some of these policies may be resented and, more basically, that some current policies conflict with customary practices and attitudes. Thus, peasants resist state-decreed limitations on family size and some judges may in practice obstruct freedom of divorce. He suggests a tension between the determination of the state to supervise and intervene in family matters and the continued resistance by Chinese society. $\mathrm{He}$ further speculates on some possibility for change as lawmakers come to realize the limits of law as a tool for moulding individual behaviour.

Law as a means of controlling official arbitrariness. Conspicuously absent from extended discussion in this issue is the use of law to control administrative arbitrariness, because little progress has been made in developing that function. The continued hold of the CCP over the courts is underlined in Clarke and Feinerman's discussion of the criminal law,

42. See "Regulations governing public offences," FBIS-CHI, 16 May 1994, pp. 15-21, a translation of the PRC Regulations for Controlling and Punishing Public Offences, adopted as amended by the Seventh Session of the Eighth National People's Congress, 12 May 1994. The statute was first adopted in 1957.

43. Clarke and Feinerman, p. 143. 
which also leaves no doubt about the breadth of police powers and the closeness of the links between criminal law and the implementation of policy under the CCP. Although there is no extended discussion of the Administrative Litigation Law, which was supposedly enacted to permit challenges to administrative arbitrariness, passing references have been made to the resistance from within the governmental apparatus that the law inspired when it was proposed. Tanner observes that

Given the strong historical orientation toward separate sector-by-sector administration in China, the prospect of making policy through a law which purports to universal applicability creates special fears amongst ministry bureaucrats.... a law such as the Administrative Litigation Law is greatly feared by many bureaucrats, since it can potentially grant courts and other bureaucratic "outsiders" the authority to intervene in a massive range of in-house ministerial activities. ${ }^{44}$

Pitman Potter observes that the Administrative Litigation Law keeps the review of abuses of discretion beyond the scope of review under the law. ${ }^{45}$ There seems no doubt that this function of Chinese law remains only potential rather than actual, and that the prospects are poor for seeing it become more manifest in the near future.

Law as a process of protecting voluntary economic arrangements. Chinese officials and scholars commonly say that China needs a more developed legal system because "a market economy is an economy governed by law," in which law provides rules like those in athletic contests. ${ }^{46}$ Recent years have seen the appearance of many market-related legal institutions, whose meaningfulness is considered from various perspectives in the articles by Clarke, Feinerman and Potter.

Clarke inquires into the ability of successful litigants in civil and economic cases to vindicate their rights in a very practical way by collecting judgments in their favour, and finds a "worryingly low execution rate" of judgments by Chinese courts. ${ }^{47}$ Some reasons are structural, including "local protectionism," a policy of protecting China's money-losing large and medium-sized state enterprises, and the immunity in practice of enterprises run by the military. Other reasons are ideological, such as strong opposition to executing judgments against the person of the losing party, and "the continued ideological force...of the Maoist

44. Tanner, p. 54, citing Pittman B. Potter, "The Administrative Litigation Law of the PRC: judicial review and bureaucratic reform" in Potter, Domestic Law Reforms in Post-Mao China, pp. 270-304. Tanner also mentions that ministries frequently seek exemptions from the coverage of new legislation.

45. Potter, p. 170.

46. "Tian Jiyun on laws for market economy"; see also "Accelerated law-making urged to boost market economy," translated from Beijing Zhongguo wuzi bao (China Materials Newspaper), 7 March 1994, p. 4 in Foreign Broadcast Information Service, JPRS Report China, 12 May 1994, pp. 14-16. Compare a more tentative formulation: "Since the convocation of the 14th CPC National Congress, a consensus has been established among many people: 10 a considerable extent, market economy means economy operated under a legal system." (emphasis supplied), "Xinhua on socialist market economy laws," FBIS-CHI, 7 July 1993, pp. 18-20 at p. 19.

47. Clarke, p. 65. 
dichotomy between non-antagonistic and antagonistic contradictions," which, applied in civil cases, dictates that the court should try to bring about a conclusion through persuasion because non-criminal matters are deemed to raise only problems of "contradictions within the people"; the absence of an "enemy" inhibits the use of judicial power. ${ }^{48}$

Clarke goes further to discuss Chinese conceptions of legal rights, which is necessarily of major importance in the evolution of Chinese law. He suggests that the Chinese notions of legal rights are "softer" than in the West, and that as a result the level of predictability created and fostered by the new legal institutions is still very low. Thus, he also notes that the courts will sometimes refuse to accept cases when they believe that enforcement of a judgment against one of the parties would be unsuccessful. ${ }^{49}$

Neither predictability nor the level of rights-consciousness need be considered exclusively in terms of Western ideals. The function of law that is performed by enhancing predictability should be considered as relative rather than absolute. Clarke notes that "economic development has not been significantly hampered by the lack in some circumstances of effective enforcement of rights" ${ }^{50}$; courts are not totally ineffective, and Clarke also suggests that legally enforceable rights are not very important in transactions in which the actors perceive mutual trust and the need for long-term relationships. Moreover, expectations about the level of predictability that a legal order is expected to foster are not the same in all cultures. Besides, movement and change are obviously possible, though they may be slow. The new legal institutions created since 1979 have helped to undergird considerable economic growth, even if they cannot yet fulfil their supposed goal of defining and helping to vindicate legal rights.

Feinerman and Potter each touch on the predictability and the definiteness of rights as they are seen by foreign investors. Feinerman concludes that although the legal infrastructure for foreign investment continues to become more complex, "Chinese conceptions of contract are a good deal more flexible than those shared by most investors from the developed countries of the industrial world." 51 Potter discusses the "indeterminacy" of the entire regulatory framework for foreign investment. His observation is vividly illustrated by a report on the accelerating quest for profit in Shanghai:

...there is no distinction between official policy and officials' references....Lawyers report that when they contact the tax bureau to ask about changes in the law...they are advised to consult the bureau's consulting company [for a substantial fee]...In the absence of laws, there are rules and then clarifications. And because these often

48. Ibid. p. 69.

49. Legal rights are also weakly defined because of ideological and political constraints on modifying certain institutions. Thus, although the need for redefining property rights is frequently reiterated, since the onset of economic reforms Chinese debate on redefining property rights has been hampered by the political and economic sensitivity of reforming many loss-incurring state-owned enterprises.

50. Clarke, p. 80.

51. Feinerman, p. 194. 
appear contradictory to confused foreign businessmen, it seems that there are no rules at all, just the arbitrary interpretation or whim of the official asked. ${ }^{52}$

The foregoing observations suggest that many foreign investors and Chinese businessmen would agree with Clarke, who states that nothing less is needed than "a whole new way of rule-making and rule-applying" if China is to make the transition to a market economy. He says "an appropriate set of corresponding legal institutions, the most important feature of which is general applicability"53 is needed. He observes that courts in the West exercise a type of wide-ranging formal authority that no governmental agency in China presently possesses, by issuing orders that cut across bureaucratic and territorial boundaries, with a potential for uniformity. Both Clarke and Dicks suggest how removed are the Chinese courts from exercising such authority.

\section{Portents for the Future}

Although China's current institutional flux makes prediction of the future configuration and fate of Chinese legal institutions risky, some major forces can be identified and it is possible to speculate on their interaction. This section first notes the growing weakness of the institutions that knit the Chinese polity together and which must ultimately provide the political context of legal institutions, and speculates on the relationship of state and society in China. It then considers important influences on Chinese legal culture.

Erosion of the party-state. Among the factors that cloud the future of Chinese law reform are the growing weakness of the Chinese apparatus of state ${ }^{54}$ and the declining legitimacy of the CCP. ${ }^{55}$ Signs that the power of the central government over the rest of the country is steadily declining are ominous. ${ }^{56}$ These include perversion of government functions by the use of existing institutions for purposes of private gain by means that include outright piracy, ${ }^{57}$ imposition of illegal and unauthorized fees,${ }^{58}$ establishment of illegal businesses by government agencies, ${ }^{59}$ bribery and

52. "Passion for profit," Far Eastern Economic Review, 23 June 1994, p. 54-56 at p. 55.

53. Clarke, p. 66.

54. See generally Yu Yin, "Phenomena of 'officials' violating discipline in exercising authority and ways to deal with them," Fazhi ribao (Legal Daily), 23 May 1993, translated in FBIS-CHI, 10 June 1993.

55. See e.g. "Xinhua reports on 4th CPC plenum decision," FBIS-CHI, 6 October 1994, pp. 13-25, at p. 18, describing the weakness of CCP "grass-roots party organizations."

56. See e.g. "The road from Tiananmen," The Economist, 4 June 1994, pp. 19-21.

57. See e.g. "Chinese pirates," Asian Wall Street Journal, 18 February 1994.

58. See e.g. "Circular on school fee collection control," translated in FBIS-CHI, 21 October 1993, pp. 24-26; "Customs administration to curb illegal fees," FBIS-CHI, 14 October 1993, pp. 14-15; "Regulations on fees borne by peasants reported," 12 December 1991 in FBIS-CHI, 10 January 1992, pp. 36-38; "Circular on fees subject to cancellation issued," FBIS-CHI, 12 November 1993, pp. 59-60 (illegal fees cancelled by Ministry of Finance, State Planning Commission).

59. See e.g. "Customs offices ordered to close tertiary businesses," FBIS-CHI, 21 October 1993, pp. 41-42; "Ban on Party, government organs doing business," FBIS-CHI, 22 July 
corruption $^{60}$ and illegal transfer of public assets. ${ }^{61}$ In the countryside "local despots" assume authority ${ }^{62}$ and farmers have been evading government attempts to control the sale and price of cotton. ${ }^{63}$ The reforms that have removed much economic behaviour from direct government control have led to new problems such as the rise of the PLA as a major economic force, ${ }^{64}$ insider trading in the new securities markets ${ }^{65}$ and capital flight. ${ }^{66}$ Tax evasion is widespread and serious. ${ }^{67}$ Beijing has been unable to enforce policies restraining inflationary growth. ${ }^{68}$ Even in the area of control over the expression of ideas government and the CCP have been unable to control the appearance of publications and publishing houses that are beyond censorship. ${ }^{69}$

Against this background, the speculations of some of the authors of articles in this issue are striking when taken together. Potter finds evidence of the decline of the central government in investment matters, and suggests the rising importance of informal and family networks in southern $\mathrm{China}^{70}$; Dicks, as previously noted, finds that law is fragmented, and the "local protectionism" that concerns Clarke clearly reflects limits on the power of the central government. The significance of these assessments seems clear, if somewhat discouraging: setting aside the issue of whether the Chinese leadership wishes to promote greater autonomy for the legal system, the current decay of the state apparatus suggests that what would necessarily be a crucial instrument in implementing that policy is being seriously weakened.

The decline in the power of the central government and in the CCP's authority and legitimacy necessarily provokes speculation about the

foomole contintued

1992; "Party, government offices ordered to sever economic ties," FBIS-CHI, 25 October

1993 p. 18, and " 'Text' of regulations," FBIS-CHI, 25 October 1993, pp. 18-20.

60. See e.g. Brewer S. Stone, "Don't get stuck in China," Asian Wall Street Journal, 23 September 1993; "Enemies in the ranks," South China Morning Post, 24 April 1994.

6I. See e.g. "Guard against the illegal transfer of public assets in the course of moving toward market economy," Liaowang, 12 April 1993, pp. 13-14, translated as "Economist on illegal transfer of public assets," FBIS-CHI, 10 May 1993, pp. 31-33.

62. See e.g. Andrew Brick, "The Emperor of Heilongcun," Wall Street Journal, 16 July 1993; Lena Sun, "For China's peasants, abuses by "warlords' adds to their misery," International Herald Tribune, 12 October 1993.

63. "Rebellion grows in China's cotton fields," Wall Street Joumal, 15 November 1994.

64. See e.g. "Soldiers of fortune: Chinese army fashions major role for itself as a business empire," Wall Street Journal, 24 May 1994, p. 1; "Gun ban to affect two Chinese firms whose big size will limit injury," Wall Street Journal, 27 May 1994.

65. See e.g. "China's regulators outgunned in war on fraud," International Herald Tribune, 18 February 1994: "As China struggles to establish rules to govern securities trading, blatant fraud and insider dealing on the country's stock markets are going largely unpunished."

66. See e.g. Philip Bowring, "China: capital flight is hurting the currency and the country," International Herald Tribune, 5 July 1993; Henny Sender, "Follow the money," Far Eastern Economic Review, 14 October 1993, p. 74.

67. See e.g. Henny Sender, "Taxing problem: Peking grapples with massive tax evasion," Far Eastern Economic Review, 25 November 1993, pp. 52-53.

68. See e.g. Gerald Segal, "China's changing shape," Foreign Affairs, Vol. 73, No. 3 (May/June 1994) pp. 43-58 at p. 45: "... Beijing's failure to implement an economic austerity package in the summer of 1993 was almost entirely due to resistance by the rich coastal provinces."

69. Orville Schell, Mandate of Heaven (New York: Simon \& Schuster, 1994) pp. 293-310.

70. Potter, p. 184. 
future of the Chinese state. One scholar has suggested a range of possible outcomes $^{71}$ :

- Continuation of the status quo, in which Leninism and CCP dictatorship exist but decentralization leads to a de facto federalism;

- A China divided into parts, with regionalism formally recognized and provincial protectionism evolving into separatism, creating instability that would require "a major military element in the governance of China's separate parts";

- Emergence of a new nation in which political pluralism and a market economy are joined (although not necessarily in a Western fashion); and

- "Authoritarian-pluralism," which the politics are authoritarian, with a single party system whose Leninism would give way to a more flexible political order subject to loosening and in which "the frontiers of permissibility would be constantly tested."

Of these, the emergence of pluralism seems least likely and the continuation of authoritarian politics most likely. In a similar vein others also suggest that the state is needed to manage Chinese reform ${ }^{72}$ and that liberal democracy is a characteristic of advanced industrial society and is more of a product of economic modernization than its cause. ${ }^{73}$

The conditions for liberal democracy that seem so unlikely to appear in the near future in China are precisely those that most Western observers would associate with creation and maintenance of a rule of law. Western models may have some impact, but they must be considered together with other forces that are likely to influence the trajectory of Chinese legal development, emanating from Chinese society rather than the Chinese state and from the Overseas Chinese.

China's legal development will be shaped not only from the top down by China's state apparatus but also by responses and pressures from Chinese society. Some foreign observers have argued that public pressures for democratization in Chinese society have been growing and that local-level democracy could well grow stronger, ${ }^{74}$ thereby raising the issue over the future of a civil society in China. The "essence" of "civil society" has been defined by Martin King Whyte as involving

the idea of the existence of institutionalized autonomy for social relationships and association life, autonomy vis-a-vis the state ... a well-formed civil society implies a degree of separation in the relationship between state and society, such that much social life goes on without reference to state dictates and policies. ${ }^{75}$

Whyte, writing after the repression of the Democracy movement, concluded that "there is some basis for optimism that a nascent civil society will survive to provide potential for a more democratic China in the

71. Robert Scalapino, "China in the late Leninist era," The China Quarterly, No. 136 (December 1993), pp. 949-971 at pp. 963-64.

72. Gordon White, "Democratization and economic reform in China," Australian Journal of Chinese Affairs, No. 31 (January 1994), pp. 73-92.

73. lbid. p. 79.

74. Ibid.

75. Martin King Whyte, "Urban China: a civil society in the making?" in Arthur Lewis Rosenbaum (ed.), State and Society in China: The Consequences of Reform (Boulder, CO: Westview Press, 1992) pp. 77-101. 
future." ${ }^{, 76}$ Even disregarding the important issue of whether the concept itself is too narrowly rooted in Western European history to be applied to China past or present, some observers would argue that "Chinese citizens appear to conceive of social existence mainly in terms of obligation and interdependence rather than rights and responsibilities."77 Others argue that the very nature of the economic reforms inhibit the development of civil society in China, pointing to the unique "interpenetration" of cadres and new merchants, both of them sharing dependence on the state. ${ }^{78}$ This argument is strongly supported by analysis that shows that most of the township and village enterprises, new economic actors, are being created by local governments rather than private individuals, and that "in many respects, local officials in rural areas have become entrepreneurs analogous to company executives."79

Relevant here, too, is the view of "non-governmental" "social organizations" and economic associations in China not as "autonomous Western-style interest groups [but] 'bridges' between society and government," intended to assist Party and government. ${ }^{80}$ Alford's comment in his article on the closeness of the relationship between the Ministry of Justice and the All China Lawyers Association is a specific illustration, then, of a general tendency. "Socialist corporatism," as some Western scholars have called it, ${ }^{81}$ today acts to obstruct wider recognition of the autonomy of individuals and non-governmental groups as bearers of rights that must be protected by the state.

Chinese legal culture and its continuing evolution. Chinese legal culture, described in passing by James Feinerman as "the fundamental attitudes of a state and its people towards law generally," 82 has contributed greatly to the underdevelopment of the elements of a legal system as it is conceived in the West. ${ }^{83}$ Mention has already been made, for

76. Ibid. p. 97.

77. Frederic Wakeman, Jr., "The civil society and public sphere debate," Modern China, Vol. 19, No. 2 (April 1992), pp. 108-139 at p. 134.

78. Dorothy J. Solinger, "Urban entrepreneurs and the state: the merger of state and society," in Rosenbaum, State and Society in China, pp. 121-141.

79. Andrew G. Walder, "Corporate organization and local government property rights in China," in Vedat Milor (ed.), Changing Political Economies: Privatization in Post-Communist and Reforming Communist States (Boulder \& London: Lynne Rienner, 1994) pp. 53-66 at p. 62, citing excellent articles by Jean Oi and Christine P. Wong on the Chinese countryside.

80. Margaret M. Pearson, "The Janus face of business associations in China: socialist corporatism in foreign enterprises," Australian Journal of Chinese Affairs, No. 31 (January 1994), pp. $26-66$ at p. 35 .

81. Ibid.

82. Feinerman, p. 190.

83. See e.g. Ronald C. Keith, China's Struggle for the Rule of Law (New York: St Martin's Press, 1994) at p. 48, referring to traditional Chinese concepts of law: "...law reinforced hierarchy and obligation rather than a notion of rights as separate from obligations." Compare also Lucian W. Pye, "China: erratic state, frustrated society, Foreign Affairs, Vol. 69, No. 4 (Fall 1990), pp. 56-74 at p. 59, arguing that because the traditional Chinese state, although it "pretended to omnipotence" had limited "policy-implementing authority ... Chinese society has gone along with the pretence of official omnipotence while following its own lead and making almost no demands on the government." A consequence was "the great Chinese 
example, of traditional undervaluing of rights. Even while traditional and socialist values dominate current Chinese legal culture, post-Maoist strains of thought and influence from abroad are acting on it as well. This section speculates on some possibly powerful sources of influence.

Chinese legal culture is not static, and the experience of this author and other frequent visitors to China provides impressionistic evidence that in Chinese society there are views of law and values related to it that vary from the leadership's instrumental use of law, and that would, moreover, promote greater legality if they were tolerated. Thus, Clarke and Feinerman observe that what Chinese today mean when they say that there is no law "is something very specific: the government is not restrained by its own rules, and it should be." 84 Potter has elsewhere tried to analyse these sentiments, and suggests that values consistent with Western ideals of equality, justice and legality are commonly expressed by Chinese at all levels of society. ${ }^{85}$ Any visitor to China can encounter many Chinese who have experienced enough instances of official arbitrariness to form the notion that a government owes it to its citizens to restrain its own power and aim at regularity and fairness in its dealings with them.

Western institutions and values have significantly influenced Chinese legislation, the creation of new legal institutions and orientations towards law. One notable example is the Chinese legislation that currently fills the role of a civil code, the General Principles of Civil Law, and which is closely modelled on the general part of the German Civil Code, which influenced the Civil Code presently in force on Taiwan. ${ }^{86}$ More generally, some Chinese law professors have been influenced by Western theories of the rule of law. ${ }^{87}$

Quite a different sort of influence may be exerted on Chinese law by the Overseas Chinese, whose capital continues to dominate the influx of foreign investment. Even while contributing much to the economic reform of China, particularly in the south, they also carry with them values that may not be conducive to the growth of a legal system.

Potter links the growing power of local officials to foreign capital, particularly investments by overseas Chinese, "heralding the potential emergence of local corporatism." Overseas Chinese "are relatively untroubled by the absence of a legal and

\section{footnote continued}

political game of feigned compliance. Central authorities issue their 'absolute' orders and local authorities proclaim their obedience, even as they quietly proceed to do what they think best. Higher authorities are hesitant to check too carefully about the implementation of their orders for fear that it might reveal their impotence and shatter the pretentions of absolute power." Pye's views are suggestive for the making and implementation of Chinese law today.

84. Clarke and Feinerman, p. 153.

85. Pitman B. Potter, "Riding the tiger: legitimacy and legal culture in Post-Mao China," The China Quarterly, No. 138 (June 1994), pp. 328-358.

86. "The Chinese civil law ... is, in effect, German civil law." William C. Jones (ed.), Basic Principles of the Civil Law in China (Armonk, NY: M.E. Sharpe, 1989), p. xvi.

87. See, for examples, Keith, China's Struggle for the Rule of Law, which, however, also concludes - without evidence - that China's leadership agrees with the writings of Chinese legal academics as Keith has summarized them.

88. Potter, p. 184. 
accounting framework or of reliable market research" and assume that they need "to co-opt political support to get anything done." ${ }^{\text {" One }}$ well-known Hong Kong Chinese businessman has been quoted as saying "Western companies take a long time to make decisions; they need a lot of lawyers. The bureaucracy is too heavy for this part of the world. Overseas Chinese know not to create such deterrents." ${ }^{90}$ Explicit here is the notion that law as practised by lawyers is an inappropriate tool for accomplishing economically constructive results. Admittedly the lengthy contracts that are usually preferred by many multinational corporations and their lawyers are often too wordy and legalistic for Chinese counterparts. The major concern among Overseas Chinese businessmen, however, may not be lawyers but rather the use of law itself. A considerably more pointed observation is that of an American banker in Hong Kong, quoted in the same article: "YYou need a partner for the local flavor when you negotiate ... and to take care of things behind the scenes.' By that he means the sometimes necessary transactions foreign firms need to distance themselves from." 91

It would be wrong, of course, to regard the values of Overseas Chinese (here admittedly caricatured rather than analysed) as monolithic or unchanging. ${ }^{92}$ Even with this caveat, however, it is still apparent to many observers inside and outside China that Overseas Chinese often value legal rules and formal arrangements fashioned to conform with them very differently from many Western and Japanese businessmen. ${ }^{93}$ These attitudes consequently colour those of Chinese in the PRC, and seem further likely to influence the future development of Chinese legal institutions. As long as the motherland continues to welcome "Overseas compatriots," the Overseas Chinese will continue to bring with them their own cultural values; those mentioned here are not conducive to the elevation of Chinese legal consciousness.

\section{Conclusion: The Difficult Path Ahead}

The articles in this issue all suggest that although much effort has been devoted to the institution-building that must necessarily precede all other law reforms, Chinese accomplishments so far amount only to a first step in what promises to be a very long journey. This introduction has pointed

89. "China's diaspora turns homeward," The Economist, 27 November 1993, pp. 33-34.

90. "Woo's new wave," Far Eastern Economic Review, 23 December 1993 pp. 38-39 at p. 39, quoting Peter Woo, Chairman of Wheelock.

91. Ibid.

92. As one observer has noted: "Some cultures do, of course, show a remarkable continuity over long stretches of time. But ... a multi-million manufacturing company in Taiwan is not simply a peasant clan writ large .... On the contrary, in some situations, people can drastically change their beliefs and their behavior, often in an amazingly short period of time." Peter L. Berger, "Is Asia's success transplantable," Asian Wall Street Journal, 20 April 1994.

93. Except, of course, when they are treated arbitrarily in China. See "Detained HK man vows to clear name," South China Morning Post, 11 October 1993, quoting a Hong Kong businessman holding an American passport who alleged that he had been illegally arrested in China because of a business dispute with a PRC partner: "I was a so-called China expert, but I have learned more in 40 days in detention than I have in 40 years of academia." 
to political, economic and cultural forces that presently contend in the arena of law reform - the ideal of the rule of law, the desire for bureaucratic regularity; adherence to Marxism-Leninism and the doctrine of Party supremacy; central-local tensions; the rise of familial networks; Western influences; and the influence of the Overseas Chinese - in the midst of declining state power, diminishing legitimacy and authority of the CCP, and a broad crisis of values. Most of these forces thrust against the growth of the rule of law.

The emphasis of several authors on legal fragmentation further underscores the significance of Clarke's observation, already mentioned, that courts are only co-ordinate with other bureaucratic agencies rather than in any way superior to them. This seems a telling indicator of the extent to which the rule of law remains not only unattained in practice but unimagined by the architects of Chinese reform. Legality remains an ideal only inconsistently supported by the leadership, and has still not been clearly distinguished from bureaucratic regularity. The reluctance to elevate the authority of the courts should not be surprising; before the Cultural Revolution the major competing Chinese views of law pitted Maoist anti-bureaucratism against bureaucratic regularity, ${ }^{94}$ which is not the same as the rule of law. Maoism has lost out, of course, but not before pulling one pole of the debate so far toward the denial of legality that current Chinese groping for the rule of law may become confused with the search for bureaucratic regularity.

Among the contending forces, however, may also be the desire to use law as an instrument for change. ${ }^{95}$ Moreover, as Alford points out, despite the limited scope for law to bring about change, "...placing too great an emphasis on law's dependence on other variables ignores law's peculiar, if limited, capacity to stimulate and consolidate other types of change, while, at least implicitly, diminishing claims of its autonomy." ${ }^{, 96}$ Legal reform may be an agent that accelerates social change by creating a vocabulary of concepts. These are now at hand to be employed by Chinese to give new definition and predictability to their relationships with each other and the state. If these are popularized, they could become tools for stabilizing the expectations of economic actors. Beyond that, it has been noted that the legal institutions provide "an alternative system of appeal or recourse" for the Chinese populace. ${ }^{97}$

The authors of the articles in this issue all seem to imply, if they do not directly assert, concern about the limits they perceive on what can be attained by building new institutions. Moreover, even if change is

94. Stanley B. Lubman, "Form and function in the Chinese criminal process," Columbia Law Review, Vol. 69 (1969), pp. 535-575.

95. Even to the point of believing that "creation of a legal regulatory mechanism can engender the very institution which the law has been created to regulate." James V. Feinerman, "Backwards into the future," Law and Contemporary Problems, Vol. 52 (1989), pp. 169-184 at p. 169.

96. Alford, p. 36.

97. See e.g. use of the courts by peasants protesting cadre arbitrariness, reported in Elisabeth Croll, From Heaven to Earth: Images and Experiences of Development in China (London \& New York: Routledge, 1994), pp. 132-33. 
promoted through the necessarily tentative construction of new institutions, decay of those that have held the Chinese party-state together for over 40 years will be destabilizing, and will act to limit the possibility of major change in the leadership's goals for legal development.

Although prospects for growth of the rule of law as that concept is understood in the West presently seem dim, it may be necessary to imagine the unimaginable. As the institutions of the party-state erode, legal rules and institutions, however incomplete and tentative by Western standards, may grow more able to exercise the functions of Western private law in the emerging sectors of the economy outside the economic plan. The current vacuum in Chinese public and administrative law could also change: a strong central leadership could conceivably shape authoritarianism to respond to popular desires for both less corruption and reduced repression, and launch perceptible movement toward the strengthening of legal institutions that could restrain arbitrary official behaviour.

Hope for major progress toward the rule of law must be restrained, currently, in the face of how much must be done to realize the promise of legal reforms in the immense and complex social arena in which they must work. The other Asian dragons with which China is sometimes compared have progressed further along the path of economic development, and all of them are experiencing pressures for legal development likely to keep them ahead of China in that realm as well. The articles in this issue suggest why, of all the Asian dragons, in expanding its legal reforms China is likely to be the most reluctant of all. 